\title{
The BAF complex in development and disease
}

\author{
Amelie Alfert, Natalia Moreno and Kornelius Kerl ${ }^{*}$
}

\begin{abstract}
The ATP-dependent chromatin remodelling complex BAF (= mammalian SWI/SNF complex) is crucial for the regulation of gene expression and differentiation. In the course of evolution from yeast to mammals, the BAF complex evolved an immense complexity with a high number of subunits encoded by gene families. In this way, tissue-specific BAF function and regulation of development begin with the combinatorial assembly of distinct BAF complexes such as esBAF, npBAF and nBAF. Furthermore, whole-genome sequencing reveals the tremendous role BAF complex mutations have in both neurodevelopmental disorders and human malignancies. Therefore, gaining a more elaborate insight into how BAF complex assembly influences its function and which role distinct subunits play, will hopefully give rise to a better understanding of disease pathogenesis and ultimately to new treatments for many human diseases.
\end{abstract}

Keywords: Rhabdoid tumour, Synovial sarcoma, Mammalian SWI/SNF complex, BAF complex, Cancer, Epigenetic, Chromatin remodelling, Neurodevelopmental disorders

\section{Background}

Packing a DNA strand, with the length of over $1 \mathrm{~m}$, into a $5-\mu \mathrm{m}$ nucleus is obviously a challenge to be met in the course of evolution. It is known that this can only be achieved by condensation of DNA with the help of histones $[1,2]$. Further compaction is engineered by additional proteins [3]. However, the DNA still needs to be accessible to the transcription machinery. In this way, organisation of DNA in chromatin is both an obstacle and an additional way of gene regulation (see Ref. [4] for a review).

Epigenetic mechanisms allow regulation of DNA expression and chromatin accessibility and include DNA methylation (see Ref. [5, 6] for reviews), histone modifications (see Ref. [7, 8] for reviews) and ATP-dependent chromatin remodelling. This review will focus on the SWI/SNF family of ATP-dependent chromatin remodelling complexes and its role in development and disease.

*Correspondence: kornelius.kerl@ukmuenster.de Department of Paediatric Haematology and Oncology, University Children's Hospital Muenster, Domagkstraße 24, 48149 Muenster, Germany

\section{Evolutionary aspects of ATP-dependent chromatin remodelling by SWI/SNF complexes}

The first subunits of the ATP-dependent SWI/SNF complex were discovered in yeast, where some of its subunits were detected in two independent genetic screenings, one for genes being responsible for the regulation of mating-type switching [9] and the other for those being able to allow changing of nutrient sources used for energy supply [10-12]. With respect to these discoveries, the term SWI/SNF complex (short for SWItch/sucrose nonfermentable) was coined and is used in other species as well [13-18].

The yeast SWI/SNF complex has a molecular weight of just 1.14 $\mathrm{MDa}$ [19] and is composed of six core subunits (Swi2/Snf2 as ATPase subunit, Swi1, Swi3, Snf5, Snf4 and Snf6) and additional Swp- and actin-related proteins (Swp29, Swp59, Swp61, Swp73 and Swp82). Consequently, it is less elaborate than its mammalian counterpart $[13,19,20]$.

In Drosophila melanogaster, Brahma (Brm) is the equivalent of the yeast Swi2/Snf2 ATPase subunit and the complex it forms with additional proteins is named BAP (short for Brahma-associated protein) complex [21-23]. This complex was first discovered in screens to uncover 
genes that are able to suppress phenotypes caused by mutations in Polycomb genes [23, 24].

Mirroring the increasing complexity of the mammalian genome compared to yeast and fly, the mammalian equivalents of the earlier discovered ATP-dependent chromatin remodellers also became more diverse [25]. The BAF complex is one of four ATP-dependent chromatin remodelling complex families known in mammals (the others being INO80/SWR1, ISWI and CHD) (see Ref. [26] for a review). In the course of evolution, some of the yeast SWI/SNF subunits stayed conserved in mammalian genes encoding the BAF complex subunits BAF250a/b (homologues of Swi1), BRG1/BRM (Swi2), BAF155/170 (Swi3), BAF60 (Swp73), BAF53 (ARP7/9), BAF47 (Snf5) and the BAF45 family (Swp 82). More recently evolved subunits such as BCL7a/b/c, BCL11a/b, BRD7/9 and SS18/CREST lack homologues in yeast [18, 27, 28].

Taking into account that the $2 \mathrm{MDa}$ mammalian BAF (short for BRG1/BRM-associated factor) complex contains up to 15 subunits [18, 25, 27, 29] and that many of these subunits are encoded by gene families and can therefore be replaced by their paralogues, it becomes clear that there are hundreds of potential assemblies possible for mammalian BAF complexes. At the same time, the high stability of subunit binding amongst each other prevents frequent subunit alterations $[27,30]$. Thus, the combinatorial assembly becomes a way to ensure complex specificity and allows the BAF complex to perform the more elaborate regulation the mammalian genome requires. Many of the resulting complexes are unique to specific tissues or biological functions such as neural development and function [31-34], heart development [35, 36], muscle development [37-39] or embryonic stem cell pluripotency $[40,41]$. Hence, it is not only the BAF complex itself that controls biological processes but the expression of distinct BAF complexes with unique subunit compositions is also a major part of the regulatory process.

BRG1 or BRM is incorporated into the complex as catalytic subunits with ATPase activity [18, 25], and in particular, their helicase domains show a high grade of conservation [42, 43]. Furthermore, BRG1 or BRM alone is able to remodel nucleosome templates in vitro without being accompanied by other subunits. Adding three other dedicated members of the BAF complex, namely BAF47, BAF155 and BAF170, this core complex reaches a remodelling activity that resembles the activity of the entire SWI/SNF complex [44]. Nonetheless, Mashtalir et al. recently questioned the idea of a core complex consisting of the ATPase subunit, BAF47, BAF155 and BAF170. Their studies revealed that the assembly of the BAF complex begins with the dimerisation of a BAF155::155 homodimer or a BAF155::170 heterodimer. This is the platform for further BAF assembly, and the core module is formed by first incorporating BAF60 and later BAF47 and BAF57. The next steps are the integration of BAF250 and later BAF45C. Not until this core intermediate is formed, can the ATPase module (consistent of BRG1 or BRM, actin, SS18, BRD7 and BAF53A) bind and complete the BAF complex [45]. Both core subunits and variable ones contain DNA- and/or histone-binding domains such as zinc fingers, AT-hooks and chromo- and bromodomains. As a result, BAF complexes do not only recognise binding sites based on DNA sequence but more importantly also based on architectural characteristics and pre-existing regulatory histone modifications [18, 46, 47] (see [48] for a review).

Concurrent with changes in subunit composition and gain in complexity in the course of evolution, the functions to be fulfilled by SWI/SNF complexes also expanded. The yeast genome mainly consists of actively expressed genes, with SWI/SNF being responsible for transcriptional activation but not for repression. In this organism, SWI/SNF predominantly targets histones and nucleosomes $[16,49,50]$. In Drosophila, on the other hand, the BAP complex mostly executes its function by opposing the Polycomb gene family $[23,51$, 52]. In comparison with yeast and fly, the total number of genes encoded by the mammalian genome is only changed to a minor degree, but the amount of regulatory elements increased substantially and large parts of the genome are in a repressed state. Reflecting this circumstance, the mammalian BAF complex is able to activate and repress genes, causing a limited comparability between the yeast SWI/SNF complex and those in more complex multicellular organisms [53-55].

Based on different subunit composition, two distinct BAF complexes have already been described. The PBAF (Polybromo-associated BAF complex) can be distinguished from the cBAF (canonical BAF complex) by the incorporation of BAF200 instead of BAF250A/B and of BAF180 [18]. Furthermore, PBAF lacks SS18 but includes the PBAF-specific subunits BAF45A and BRD7 $[54,56]$. Nonetheless, most recent studies question the existence of only two distinct BAF complex subgroups by describing a third class, called ncBAF (for noncanonical BAF complex) or GBAF (after its distinctive subunits GLTSCR1/1L) [57]. It lacks many of the dedicated cBAF subunits such as BAF47, BAF57 and BAF250 and the PBAF-specific subunits BAF180 and BRD7. In addition, it always contains a BAF155::155 homodimer and BAF60A instead of BAF60B or 60C and is further characterised by the incorporation of BRD9 and GLTSCR1/1L $[45,57,58]$. 


\section{The role of BAF complexes during mammalian development}

As already mentioned, distinct subunit compositions occur at different time points during development and in different tissues, underlining the importance of combinatorial assembly in functional specificity of the BAF complex. Three especially well-studied complex assemblies are esBAF, npBAF and nBAF.

\section{esBAF complex and its role in embryonic development}

Embryonic stem cells (ESCs) are characterised by the ability to self-renew and to differentiate into all cell lineages of the adult organism. This is, in part, achieved by the expression of pluripotency-related transcription factors such as OCT4, SOX2 and NANOG [59-63]. Since the genetic code remains unaltered in all tissues, the relevance of epigenetic control of chromatin assembly and accessibility as well as of gene expression itself becomes exceedingly clear. Besides these unique abilities of embryonic stem cells, they are also characterised by a unique chromatin structure (e.g. a high amount of bivalent domains [64]). The assembly of an ES cell-specific $\mathrm{BAF}$ (esBAF) complex is required for regulation of the ES cell transcriptome. The esBAF complex is, in contrast to BAF complexes in other cells, marked by the dependency on BRG1 as ATPase subunit (while BRM is not included in the esBAF complex). Moreover, it is distinguishable by the incorporation of Baf250a not 250b, Baf60a/b not 60c and a Baf155::155 homodimer instead of a Baf155::170 heterodimer in murine ESC $[41,54]$. In human ESC BAF170, and not BAF155, seems to play an important role in the maintenance of pluripotency [65].

A possible way of elucidating the role and importance of individual subunits of multiprotein complexes in vivo is the creation of mouse strains that lack these subunits. Unfortunately, loss of Brg1, Baf155 or Baf47 is lethal to these animals at a very early embryonic stage. Both Brg1 and BAF155 knockouts are peri-implantationally lethal and Baf47-depleted embryos do not survive beyond day 7.5 [66-69]. Even if this fact emphasises the importance of these subunits for early embryonic development and stem cell function, it makes further research particularly difficult. Interestingly, Brm-knockout mice reach adulthood and are fertile with the only difference to their littermates being a slightly increased body size [70].

Regardless of the lethality of core-subunit loss in vivo, (conditional) knockdown (KD) or knockout (KO) experiments of distinct esBAF subunits proved themselves to be a promising technique to study their role in in vitro experiments with embryonic stem cells. Depleting cells of Brg1 leads to both a loss of self-renewal and a decrease in proliferation followed by a diminished expression of the core pluripotency-related factors Oct4, Sox 2 and
Nanog and loss of pluripotency. A Baf155 knockout in ESCs results in a similar phenotype [41]. Corresponding to the unique subunit composition of esBAF, neither Brm nor Baf170 overexpression can rescue Brg1 or Baf155 knockout, respectively. A forced expression of Baf170-containing complexes also results in the inability of the transfected cells to form teratoma, indicating a loss of pluripotency [41, 67]. This cannot be observed when depleting mouse embryonic fibroblasts (MEFs) or glial cells of Brg1 [31, 67], once again highlighting the distinct requirements of the ES cell genome.

Furthermore, chromatin immunoprecipitation experiments followed by sequencing (ChIPseq) allowed a more specific detection of esBAF binding to the genome. It was detected that Brg1 binds to approximately four percentage of the mouse genome with binding sites located in genic and promoter regions as well as in intergenic regions. Both Brg1 and Baf155 are enriched near the transcriptional starting site (TSS) and at least in part resemble the binding patterns of core pluripotency factors Oct4, Nanog and Sox2 [40]. Murine ESC pluripotency is also ensured by the leukaemia inhibitory factor (Lif) and the Stat3 pathway that is activated by Lif. STAT3 signalling also plays a role in human embryonic stem cell pluripotency [71-73]. Interestingly, Brg1- and Stat3-binding sites display a substantial genome-wide overlap in mESC. Changes in gene transcription upon Brg1 knockout resemble those being caused by LIF withdrawal. Stat3 binding is considerably impaired in Brg1depleted ES cells. This causes loss of Stat 3 binding at over $80 \%$ of sites bound by Stat3 in wild-type cells [53]. In the same publication, Ho et al. also observed changes in Polycomb function that followed Brg1 loss and will be discussed in the following.

In addition to the long-known esBAF, the newly discovered ncBAF complex also plays an important role in the regulation of the ESC transcriptome. Gatchalian et al. showed that ncBAF and esBAF differ in their localisation-while esBAF preferably binds to H3K4-monomethylated enhancers as well as to super enhancers, ncBAF seems to prefer H3K4-trimethylated promoter regions. One of the most striking differences is, however, that ncBAF binds to TAD (topologically associating domain) boundaries and CTCF sites and might in this way play a role in the regulation of chromatin organisation [58, 74].

As already mentioned, esBAF functions in close association with the core pluripotency factors Oct4, Nanog and Sox 2 [40]. ncBAF, on the contrary, seems to function by distinct mechanisms. It is associated with the transcription factors Klf4 (Kruppel-like factor 4) as well as with Sp5 (specificity protein 5 ). This interaction allows the ncBAF complex to protect naïve pluripotency and to prevent ESC priming towards epiblast ESCs [58]. In the 
same publication, Gatchalian et al. also hypothesised that Brd9 is essential for chromatin binding and might, in association with Brd4, replace BAF47 in its function to guide the ncBAF complex to its target genes.

Nonetheless, the ncBAF complex is not only restricted to ESCs but can also be found in other cell lines like HEK293T as well as in synovial sarcoma and malignant rhabdoid tumour cell lines [74].

\section{npBAF and nBAF complexes in neural development}

Neural development is a well-studied example of how specification of BAF complexes is achieved by distinct combinatorial assembly. During differentiation from ESCs to neural stem cells (NSCs), the neural progenitor BAF (npBAF) complex evolves and, accompanied by the final neurogenic cell division, changes into the neuronal BAF (nBAF) complex. Compared to the BAF subunits in ES cells, some subunits (Baf45a/d, Baf53a and SS18) are preserved and ensure self-renewal and proliferation of the cells that give rise to the nervous system, while others undergo changes. Brm can be incorporated as ATPase subunit instead of Brg1 and so can Baf250a be replaced by $250 \mathrm{~b}$. Instead of the Baf155::155 homodimer, the npBAF complex can include a Baf155::170 heterodimer and Baf60c replaces BAF60a/b [31, 34, 75].

Heterozygous loss of $B r g 1$ and Baf155 leads to defects in neural tube closure $[67,76]$. Furthermore, $B r g 1$ depletion in Nestin ${ }^{+}-\mathrm{NSCs}$ results in severe defects of proliferation and formation of the neural progenitor pool, causing thinning of the cortex and midbrain as well as a deficiency in cerebellar development, leading to perinatal death of the animals [77, 78]. Consistent with findings in ESCs, loss of subunits specific to npBAF (Baf53a, Baf45a/d and SS18) gives rise to proliferation defects in NCSs. Whereas ES cells are still able to proliferate, when being depleted of SS18 until only 20\% of wild-type levels are left, NSCs are much more sensitive to SS18 knockdown, losing their ability to self-renew after a reduction of $25 \%$ compared to wild-type levels [75].

The shift from npBAF to nBAF coincides with the mitotic exit of neural precursors and is distinguishable by the replacement of Baf53a by 53b, SS18 by CREST, Baf45a/d by Baf45b/c and changed expression levels of Baf155 and Baf170 [31, 32, 79]. This switch has to be regulated strictly, as both premature and delayed expression of nBAF-specific subunits cause severe phenotype alterations, either showing a decrease in proliferation (see above) or disturbances in dendritic processes [80]. This is, most likely, achieved by a regulatory circuitry involving neural-specific miRNAs. miRNA9* and miRNA124 are both specifically expressed in neural cells, and their expression is repressed by REST (repressor element1 -silencing transcription factor) in neural progenitors
[81-84]. Even if both these miRNAs can, in theory, target the 3'-UTR of BAF53a, they do not influence its expression as long as REST inhibits their action [85]. In postmitotic neural cells, however, REST itself is repressed by RAR (unliganded retinoic acid receptor complex) [86]. In this way, miRNA9* and miRNA124 can target BAF53a, which leads to its degradation and loss from the npBAF complex. Additionally, BAF53a expression seems to be linked directly to BAF53b repression, and following the loss of BAF53a, BAF53b is expressed [85]. This regulatory mechanism was shown to be so powerful that it is possible to convert fibroblasts into functional neurons by overexpressing miRNA9* and miRNA124 in these cells $[75,87]$. For a more detailed description of the role of miRNA9" and miRNA124, see Ref. [88].

nBAF subunits have an enormous influence on various aspects of neural development and plasticity. They are essential for dendritic morphogenesis [79, 89]. Bcl11b regulates neuronal subtype maturation [90, 91], and Baf53b is involved in learning and long-term memory [33]. Moreover, BAF complexes in general control adult neurogenesis [92, 93], gliogenesis [92, 94] and neural morphogenesis [34, 79, 95-97].

Nonetheless, not only embryonic stem cells and neural development are dependent on BAF complex regulation. Baf60c-containing complexes, for instance, are essential for heart development, and they mark embryonic tissues with cardiogenic potential and, in association with tissuespecific factors, administer the differentiation from fibroblasts to cardiomyocytes [35, 36, 98]. Similar principles are valid for skeletal muscle development [99], and it is probable there are many more specific BAF complexes yet to be discovered. In Fig. 1, an overview of BAF subunit switches during mammalian development is shown.

\section{Mechanistic insights into chromatin remodelling by BAF complexes}

From yeast ATP remodelling complexes, it is known that they primarily fulfil their function by mobilising and exchanging nucleosomes or by moving them across the DNA [100]. On account of the structural similarities between many yeast and mammalian subunits, it was presumed that this is also true for mammalian BAF complexes. One of the first hypotheses concerning the mechanistic way ATP-dependent chromatin remodelling works was the "twist diffusion" model that postulates that the nucleosomes slide alongside the DNA strand as a reaction to the DNA twisting around the nucleosome. However, it was shown that experimental setups, that should be large obstacles for this twisting (such as biotin crosslinks, DNA hairpins or nucleosomes linked to magnetic beads), failed to inhibit nucleosome remodelling in vitro $[101,102]$. Following these experiments, the 


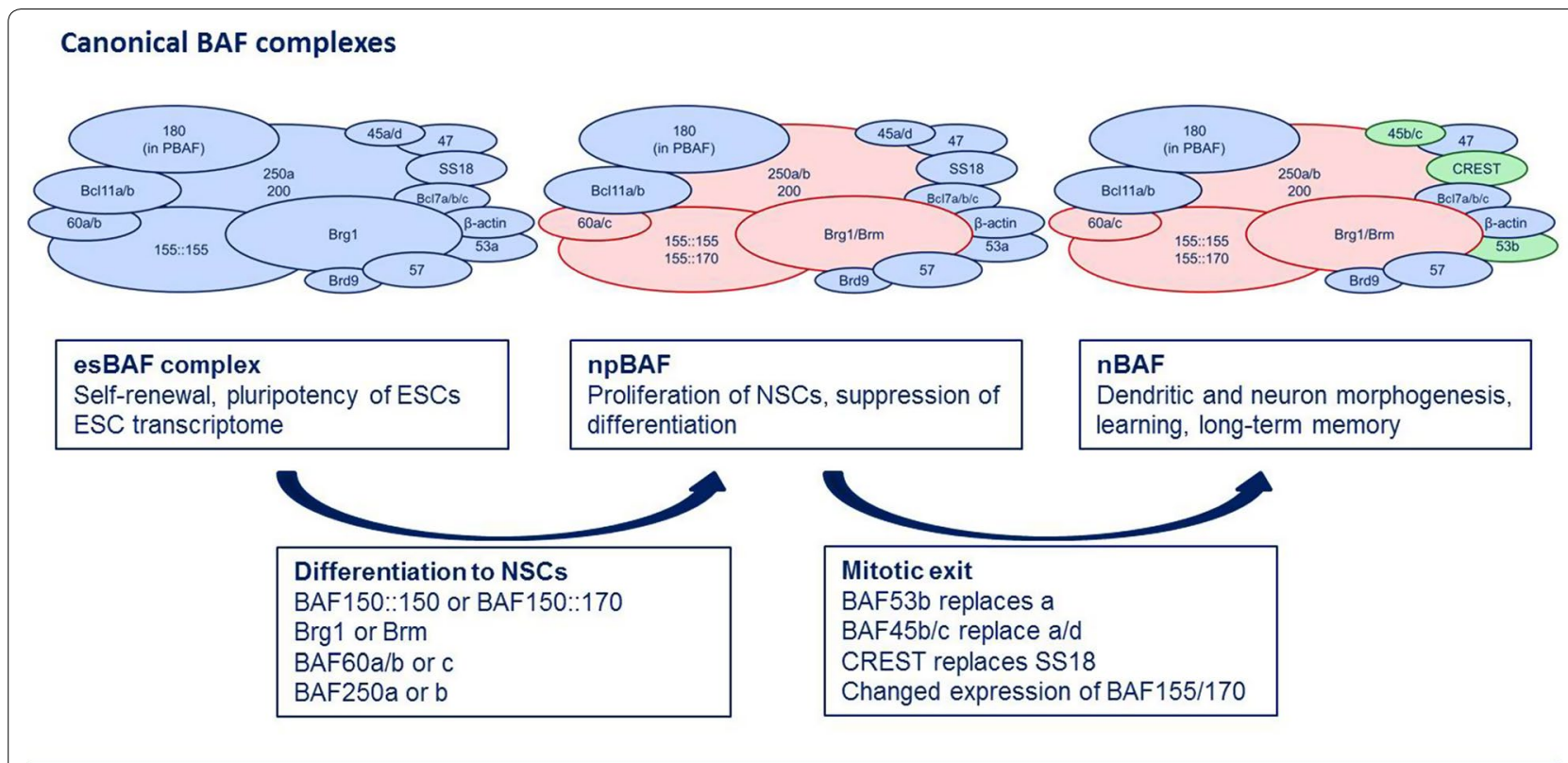

\section{Non-canonical BAF complex}

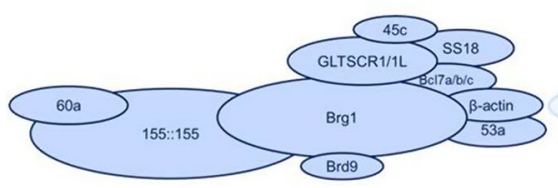

ncBAF complex

Naïve pluripotency, prevents epiblast priming

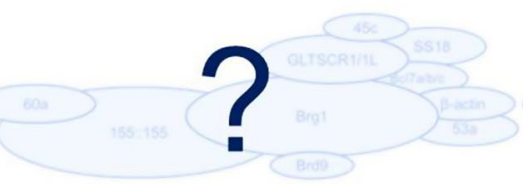

Progenitor cells

Special function?

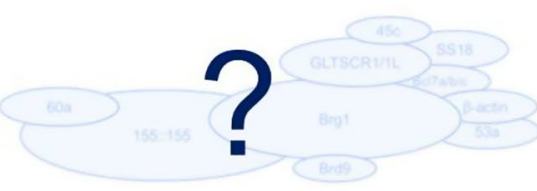

Mature cells

Special function?
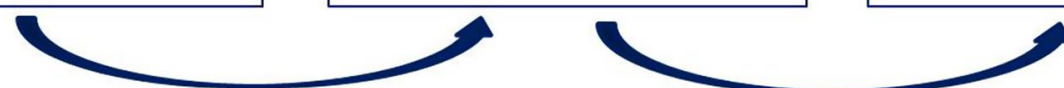

Fig. 1 BAF complex subunit switches during mammalian development. BAF complex subunits undergo distinct switches during development to adapt to the requirements of more differentiated cell types. While the esBAF complex can only be found in embryonic stem cells and incorporates BRG1 as ATPase subunit, npBAF complexes can be found in neural progenitor cells and nBAF complexes first occur with mitotic exit. Colours are used to indicate the changes in subunit compositions. Most strikingly, npBAF can include BRM as alternative to BRG1, BAF250b as alternative to a, BAF60c as alternative to $c$ and a BAF155::170 heterodimer to replace the BAF155::155 homodimer. nBAF-specific subunits are BAF53a, BAF45b/c and CREST. The ncBAF coexists with the esBAF complex in ESCs and has been shown to regulate naive pluripotency by interacting with the transcription factors KLF4 and Sp5. It is characterised by the lack of many esBAF-specific subunits such as BAF250a, BAF47 and BAF57 and the incorporation of BRD9 and the ncBAF-specific subunit GLTSR1/L1. Until now, ncBAF complexes, apart from ESCs, could also be found in rhabdoid and synovial sarcoma tumour cell lines as well as in HEK293T cells

"loop recapture" model was developed. It assumes that the DNA forms a loop via the formation of new contacts to histones and in association with the translocase activity that many ATPase subunits (also from other remodelling complexes) have, loop formation allows a shift of nucleosomes alongside the DNA [102-106].

Regardless of these remodelling mechanisms, it is remarkable that most of the BAF subunits are not needed for in vitro chromatin remodelling [44]. Nonetheless, loss of subunits not needed for in vitro function, such as Baf53a or Baf250a, causes severely altered phenotypes resembling those of Brg1 loss, while there are many amongst the most frequently mutated subunits in cancer that are not necessary for in vitro function [107-109]. This clearly indicates that the exact mechanisms of chromatin remodelling are not yet understood and that there is also the need for a better model to study chromatin remodelling in vitro. 
BAF-Polycomb opposition as an important mechanism of chromatin remodelling

The Polycomb gene family has first been discovered in Drosophila followed by the observation of male flies with ectopic sex combs [110-115].

In mammals, the multiprotein-containing Polycomb repressive complexes (PRC) have repressive influence on the genome. Similar to the BAF complexes in mammals, there are several different subunit compositions possible. PRC1 and PRC2 work in a rather different manner. PRC1 is (in its canonical form) composed of CBX, PHC, PCGF, RING and SCMH proteins with each having various variants. Additional diversity is enabled by the assembly of non-canonical complexes, in which $\mathrm{SCMH}$ is replaced by RYBP or YAF2. It typically represses gene expression by transferring a single ubiquitin to lysine 119 of histone 2A (H2AK119ub1) (see [28] for a review). PRC2 is formed by at least five subunits, namely EZH1 or 2 as catalytic subunit, EED, SUZ12, RBBP4/7 and AEBP2, with EZH1/2, EED and SUZ12 being indispensable for complex function [116, 117]. EZH1 and 2 both catalyse the SAM-dependent trimethylation of lysine 27 of histone 3. They are the only known mammalian enzymes capable of depositing this repression mark [117-119].

In Drosophila, it is well known that BAP complexes mainly function by opposing Polycomb genes [23, 24]. In recent years, it also became evident that the same principle can be found in mammalian cells as well and that this opposition is important for normal cell function. Its disruption can be responsible for tumour formation (see below). In embryonic stem cells, loss of Brg1 leaves overall expression levels of PRC2 subunits and genome-wide H3K27me3 levels unchanged. Nonetheless, there are substantial changes following knockdown: Brg1-repressed genes show a significant decrease in H3K27me3, whereas Brg1-activated genes show elevated levels of this repressive histone mark. It is shown that Polycomb and BAF complexes oppose each other at nearly all gene loci except for the Hox loci, where both act synergistically in mESCs. The phenotype caused by Brg1 deletion can be rescued by knockdown of Suz12, indicating the important role the loss of Polycomb opposition has for the changes of chromatin accessibility [53].

In order to be able to study chromatin remodelling processes in a more precise and a more realistic manner, a new method has been developed that enables experiments in mouse cells instead of using artificial nucleosome templates. This model is called CiAO (short for chromatin in vivo assay at Oct4) and allows the recruitment of the BAF complex to the Oct4 locus by a chemical inducer of proximity (like rapamycin), followed by the investigation of the effects of this recruitment [120]. Utilising this technique, it is shown that minutes after recruitment of BAF to Oct4, PRC2 is removed, with its accompanying mark H3K27me3 disappearing about 10 min after PRC2 loss. PRC1 eviction from the Oct4 locus can be detected even earlier and coincides with parallel loss of H2AK119ub1. The corollary is also true, in that BAF removal is rapidly followed by Ezh2 (PRC2) and H3K27me3 reappearance [121]. This "indirect" mechanism of chromatin remodelling is dependent on Brg1 and its ability to bind PRC1 subunits directly. Loss of Brg1 causes weakening of the interaction and increases occupancy of PRC1 and PRC2. Furthermore, the opposition of Polycomb complexes is ATP dependent, illustrated by the fact that mutations in the ATPase domain cause the same epigenetic changes as a complete loss [122]. Being most relevant for the explanation of cancer formation, even a heterozygous mutation of the ATPase domain is sufficient to significantly alter chromatin accessibility [123]. The consequences of other cancer-related changes in BAF-Polycomb opposition will be discussed in the following.

\section{The role of BAF complexes in human disease The BAF complex in neurodevelopmental disorders} With regard to the importance of the BAF complex and distinct subunit switches in neural development, it is not surprising that mutations in BAF-coding genes are associated with neurodevelopmental disorders such as Coffin-Siris syndrome, Nicolaides-Baraitser syndrome or autism spectrum disorders.

One of the syndromes commonly caused by mutations in BAF subunits is the Coffin-Siris syndrome (CSS), first described in 1970 as a combination of intellectual disability, growth retardation, joint malformations and brachydactyly combined with hypoplastic or missing fingernails at the fifth finger/toe [124, 125]. These characteristics can be accompanied by coarse facial features, numerous organ abnormalities (cardiovascular, gastrointestinal or genitourinary) and feeding difficulties [126, 127]. The most frequently mutated gene in Coffin-Siris syndrome is BAF250b, being mutated (dependent on the cohort) in at least $68 \%$ of cases $[128,129]$. BAF $250 \mathrm{~b}$ is also the subunit most frequently mutated in SWI/SNF-related intellectual disability disorders in general [130]. Whereas its paralogue BAF250a can also be detected in CSS [131, 132], it has a much more dominant role in cancer (see below). ATPase subunits BRM and BRG1 are also related to CSS $[129,133,134]$. BAF47, the subunit known to be responsible for rhabdoid tumours [135], gives rise to a severe form of CSS [136].

The Nicolaides-Baraitser syndrome (NCBRS) is an intellectual disability disorder less variable than CSS. It is characterised by seizures, prominent interphalangeal joints without signs of inflammation, severe intellectual 
disability with speech delay, growth retardation and characteristic facial features [137]. It is primarily caused by missense mutations in the alternative ATPase subunit BRM [138-140]. In conformity with the previously mentioned difference between BAF250a (mostly in cancer) and BAF250b (in neurodevelopmental disorders), BRM is the ATPase subunit predominantly associated with intellectual disabilities, while its paralogue BRG1 is more closely related to cancer (see below).

In addition to Coffin-Siris syndrome and NicolaidesBaraitser syndrome, there are many other neurodevelopmental disorders related to BAF subunit mutations, such as Kleefstra's syndrome [141, 142], disorders of the autism spectrum [143, 144], amyotrophic lateral sclerosis [145] and schizophrenia [146, 147]. For a more detailed review concerning the role of BAF complexes in neural developmental disorders, see Ref. [148-150]. BAF subunit mutations and their implication in human developmental disorders are summarised in Fig. 2.

\section{The BAF complex in cancer}

Given its immense influence on both differentiation and gene expression in general, it is not surprising that BAF complex subunits are frequently altered in cancer with up to $20 \%$ of human cancers bearing mutations in this ATP remodelling complex. Thus, it is the chromatin remodelling complex most frequently involved in human malignancies [27]. Mirroring the tissue specificity of BAF complex assembly, the influence of subunit mutations depends on the BAF complex assembly and the tissue in which they occur. Some are only occasionally associated with cancer, while others show a much higher mutation frequency. Furthermore, each is related to only a distinct subset of cancer entities. Moreover, some mutations only cause tumorigenesis when biallelic loss occurs, whereas in other cases a mutation in one allele is detected [135, 151]. The best studied examples of how mutations of chromatin remodellers can cause malignancies are BAF47 $(=$ SmarcB1) loss in rhabdoid tumours and the SS18-SSX fusion protein in synovial sarcoma. These two examples show that the BAF complex can act as both oncogene and tumour suppressor.

\section{The BAF complex as tumour suppressor}

Rhabdoid tumours are aggressive malignancies occurring in early childhood arising in the brain (atypical teratoid/ rhabdoid tumours $=\mathrm{AT} / \mathrm{RT}$ ), soft tissue (malignant rhabdoid tumours $=\mathrm{MRT}$ ) or kidneys (rhabdoid tumours of the kidney=RTK). Almost all of them show a biallelic loss of BAF47, but have an otherwise low mutational burden with no additional recurrent mutations detectable. Thus, rhabdoid tumours can mainly be considered as an epigenetic disease caused by the loss of the recessive tumour suppressor BAF47 [135, 152]. Moreover, this clear correlation between loss of BAF47 and tumour formation can be remodelled in mice. Conditional knockout

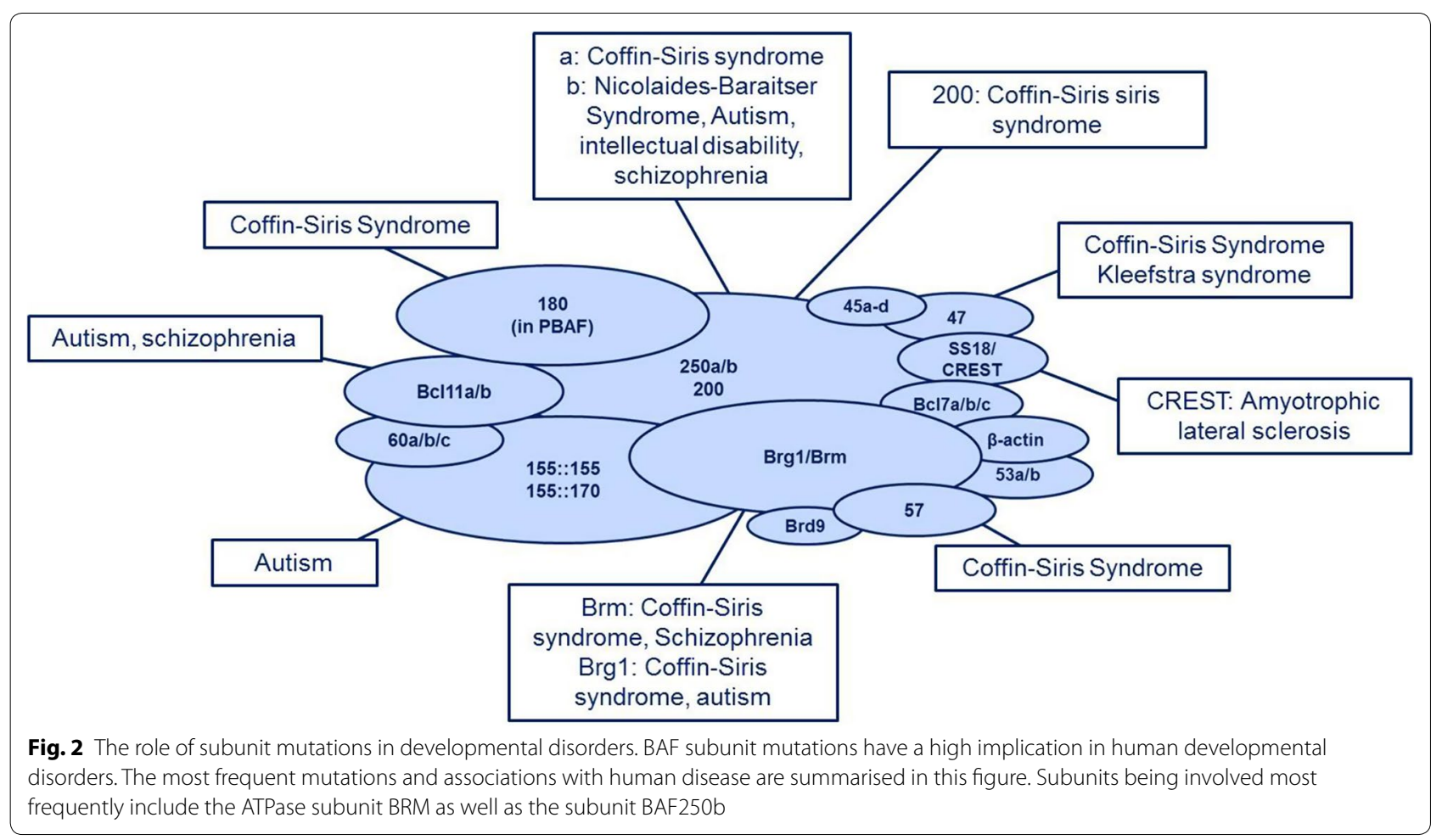


of BAF47 at a distinct time point leads to tumour formation after 11 weeks with a penetrance of $100 \%$, illustrating that loss of BAF47 is sufficient to drive tumour formation. Other studies have shown that loss of heterozygosity can also cause peripheral $\mathrm{T}$ cell lymphoma $[153,154]$. In addition, BAF47 loss also occurs in a high subset of epithelioid sarcoma [155].

Mechanistically, it is known that BAF47 plays a crucial role in BAF-mediated chromatin remodelling. Upon loss of BAF47, the BAF complex itself is still able to assemble $[156,157]$ but displays a diminished chromatin affinity. Dissociation of BAF complex and chromatin requires harsher conditions after BAF47 rescue. Consistent with this, genome-wide BAF complex occupancy increases significantly after BAF47 rescue. Furthermore, it results in a widespread enhancer and super-enhancer activation as well as an alteration in bivalent promoter regulation [158]. As already mentioned, a key factor in BAF function is Polycomb opposition. In support of this, EZH2 has been shown to be a key player in many malignancies, including rhabdoid tumours [159] (also see Ref. [160] for a review). BAF complexes deficient of BAF47 can still be recruited to the genome but are unable to evict Polycomb, as they usually do [121]. As a result, tumour cells show an increase in the H3K27me3 repressive mark, amongst others, at the p16Ink4a tumour suppressor locus, which is known to drive rhabdoid tumour formation $[159,161]$. Relevant to translational research, it has also been shown that additional inactivation of EZH2 in BAF47-deficient MEFs results in wild-type levels of p16Ink4a [159] and that tumour regression in MRTs can be achieved by chemical inhibition of EZH2 [162, 163]. Currently, a number of EZH2 inhibitors are tested in phase I/II clinical trials in other cancer entities [164, 165]. Interestingly, the expression of other BAF complex subunits like BRM seems to determine the sensitivity of tumours with BAF subunit mutations to EZH2 inhibition, suggesting BRM expression as a possible biomarker for therapeutic response [166]. For those tumours that are insensitive to EZH2 inhibition, BRM inhibition could be a promising alternative [167-169].

Despite the described role of the cBAF complex in rhabdoid tumours, there are also recent studies suggesting an auxiliary role of the ncBAF complex. Krämer et al. showed that BRD9 inhibition results in a decrease in cell proliferation as well as a G1 cell cycle arrest and an increase in apoptosis in several rhabdoid tumour cell lines [170]. This is also supported by CRISPR-Cas9-based screens, identifying BRD9, GLTSCR1 and BAF60A, all being subunits of the ncBAF complex, as critical for rhabdoid tumour cell line survival [74]. ChIPseq experiments using BRD9 and BRG1 antibodies suggest that many of the residual BAF complexes in rhabdoid tumours are, in fact, ncBAF complexes. They localise to enhancers that have already been identified as tumour associated and rhabdoid tumour specific. In this way, ncBAF preserves gene expression at CTCF sites as well as in promoterproximal regions. The unique dependency of rhabdoid tumours on ncBAF complex function might make BRD9 or GLTSCR1 inhibition an additional promising target for rhabdoid tumour treatment [74].

There are also other cancer entities, in which the BAF complex loses its tumour-suppressive abilities. Mutations of BRG1, for instance, occur in over $90 \%$ of small cell ovarian cancers $[171,172]$. BAF250a mutations, the subunit most frequently mutated in human malignancies, can be found in a huge subset of cancers, e.g. endometrial carcinoma, gastrointestinal carcinoma (colorectal, gastric), pancreatic carcinoma and cholangiocarcinoma [173-178]. Amongst the subunits less frequently involved in cancer are BAF170 (in gastric and colorectal cancer with microsatellite instability) [179], BAF155 (in small cell lung cancer) [27] as well as BAF45d and BAF60 in breast cancer $[31,180]$.

\section{The BAF complex as oncogene: the SS18-SSX fusion in synovial sarcoma}

Similar to rhabdoid tumours, synovial sarcomas are tumours in which one single, well-characterised mutation can be found in nearly all patients. It is an aggressive sarcoma arising in the soft tissue and specified by a $\mathrm{t}(\mathrm{X} ; 18)$ chromosomal translocation, fusing 78 amino acids of the protein SSX to the dedicated BAF complex subunit SS18 [151, 181, 182]. Nonetheless, the mechanism underlying the transformation is an entirely different one. Unlike rhabdoid tumours, which are caused by a biallelic loss of BAF47, tumour formation in synovial sarcoma occurs in spite of a remaining wild-type allele. This might be possible because the transcription of the wild-type allele is decreased in sarcoma cells in general. Additionally, the SS18-SSX fusion protein is preferably incorporated into the complex, leading to the degradation of the monomeric wild-type protein [27, 183]. Besides, BAF47 is almost completely lost from the BAF complex upon SS18-SSX incorporation, but in contrast to rhabdoid tumours, the ability to oppose PRC1 and PRC2 is preserved regardless of the changed subunit composition [121, 151]. Furthermore, BAF47 rescue and the following restoration of enhancer action are not necessary to decrease proliferation in synovial sarcoma [184]. Therefore, synovial sarcoma is primarily driven not by BAF47 loss, but by the gain of SS18-SSX which seems to be the driving force.

Indeed, SS18-SSX causes broad changes in BAF complex targeting and results in loss and, perhaps more importantly, a gain of chromatin occupancy by BAF 
complexes. SS18-SSX-containing BAF complexes show an unusual co-occupancy with PRC2, amongst others, at the SOX2 and PAX3 loci, which results in the eviction of Polycomb and the loss of H3K27me3 [121, 184]. These changes are sufficient to cause SOX2 expression, which is a typical feature of synovial sarcoma cell lines, that show stem cell-like expression patterns [151, 185]. Moreover, recent studies indicate that the SS18-SSX-containing BAF complex interacts with KDM2B and uses its demethylase activity to activate genes usually repressed [186]. Regardless of the substantial changes the SS18SSX fusion protein gives rise to, the original assembly of the BAF complex (containing SS18 and BAF47) can be rescued by either overexpression of wild-type SS18 or SS18-SSX knockdown. Both lead to a proliferation arrest $[151,184]$. Being mindful of the immense effect the specific inhibition of the fusion gene bcr-abl has in CML (chronic myelogenous leukaemia) [187, 188], targeted therapy with inhibitors against SS18-SSX could be a new approach to treat synovial sarcoma, as already suggested by Kadoch and Crabtree [189]. Figure 3 shows an outline of BAF subunit mutations in human cancers.

Similar to the findings in rhabdoid tumours, ncBAF also seems to play a significant role in synovial sarcoma as cell lines of this tumour entity are sensitive to the loss of BRD9, BAF60A or GLTSCR1. SYO-1 cells react with a decrease in proliferation, a G1 phase arrest and an increase in apoptosis upon treatment with BRD9 inhibitors. Other sarcoma cell lines do not show this dependency on BRD9 which makes it a specific target in cancers with $\mathrm{cBAF}$ perturbations [74, 190]. In contrast to the canonical BAF complex, ncBAF preferably incorporates SS18 not SS18-SSX [74]. Nonetheless, other experiments could show the existence of BRD9 and SS18-SSX-containing complexes with BRD9 and SS18-SSX co-binding on the genome [190]. Even if the cells are clearly dependent on ncBAF function, BRD9 inhibition neither inhibits SS18-SSX-mediated gene activation nor is it required for the de novo activation of these genes by SS18-SSX. Unlike cBAF, ncBAF is only influenced in its localisation to a minor degree. It still localises to H3K4-trimethylated regions as well as to CTCF sites and most genes that are downregulated following BRD9 inhibition are independent from the SS18-SSX fusion protein. For this reason, Michel et al. [74] suggested that ncBAF might be responsible for maintaining the gene expression of indispensable genes that are no longer activated by the re-targeted SS18-SSX-containing BAF complex. The dependency of synovial sarcoma on BRD9 could make BRD9 inhibition a promising target for therapy of this cancer entity. For this purpose, targeted BRD9 degradation might even be more effective than the inhibition of its bromodomain [190].

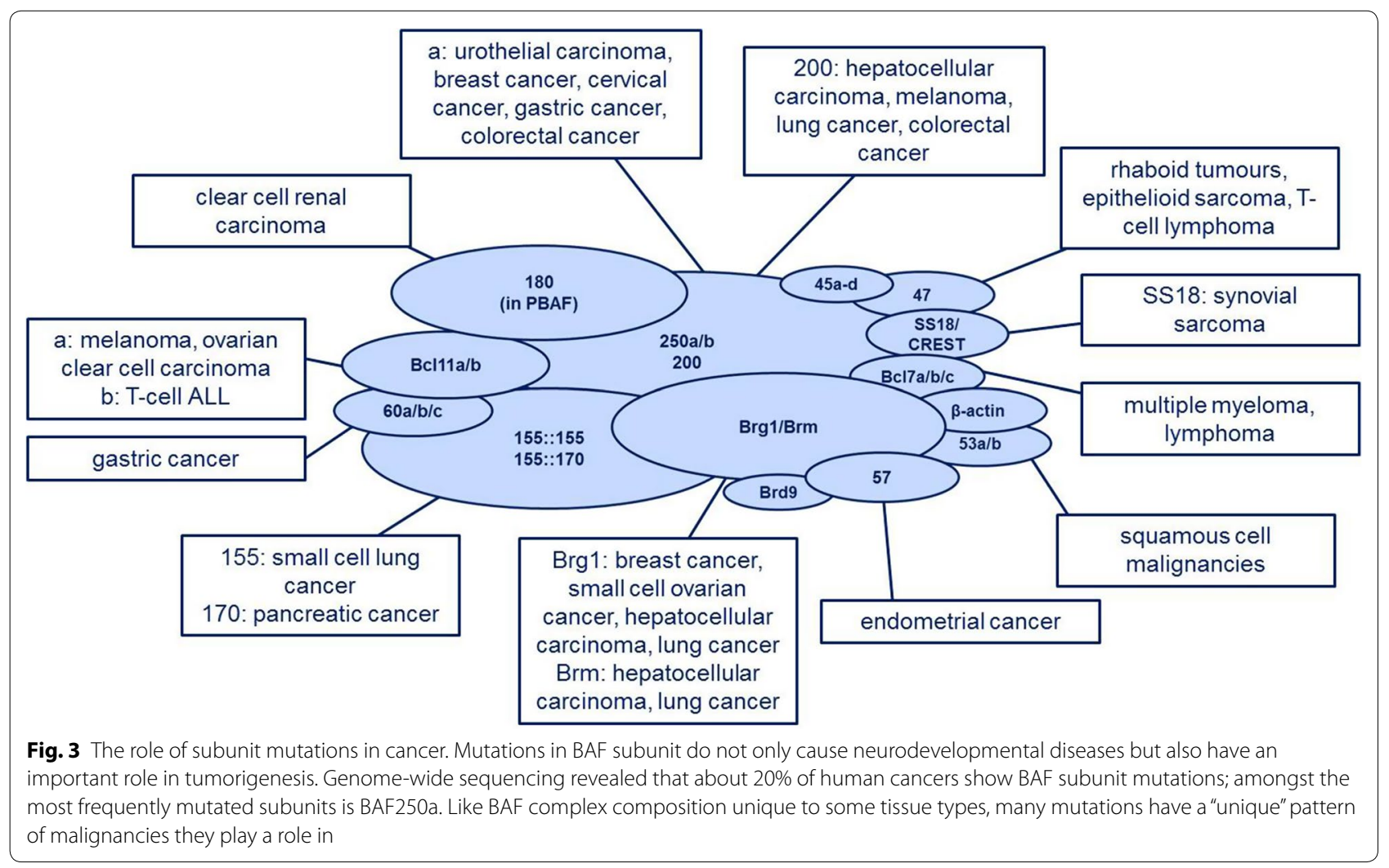




\section{Conclusion}

Evidently, a functioning BAF complex is indispensable to both differentiation of embryonic stem cells into mature cell lines and regulation of the transcriptome of these cells. Even if there has been an enormous gain in understanding how BAF complexes assemble and function in vitro, their in vivo function and the role of distinct subunits still remain an enigma. Why different mutations of the same subunit, e.g. BAF47, can cause neurodevelopmental disorders or human malignancies, is still unclear. Furthermore, the question why some subunits only cause tumour growth when both alleles are lost, while in other tumours only heterozygous mutations are detected, continues to be unanswered.

However, the discovery of EZH2 inhibitors and BRD9 inhibitors as possible therapeutic approaches for some cancers with BAF subunit mutations, illustrates why the comprehension of the precise mechanism by which subunit mutations result in tumour growth, is so important. Currently, therapeutic options of many cancers are limited by the toxicity of the therapy itself and can scarcely be made more aggressive. Therefore, developing targeted therapies that address the distinct mechanisms by which tumour growth can be driven is indispensable to improving patient survival. However, these mechanisms first need to be fully understood making further elucidation of how BAF subunit mutations drive tumour formation essential. Consistent with this, the cause of neurodevelopmental disorder cannot be understood without understanding the role of BAF complexes in early and late neurogenesis.

\section{Abbreviations \\ AT/RT: atypical teratoid/rhabdoid tumours; BAF complex: BRG/BRM-associated factor complex; BAP complex: Brahma-associated protein complex; ChIP: chromatin immunoprecipitation; ChIPseq: chromatin immunoprecipitation followed by sequencing; $\mathrm{CiAO}$ : chromatin in vivo assay at Oct4; CML: chronic myelogenous leukaemia; CSS: Coffin-Siris syndrome; esBAF complex: embry- onic stem cell-specific BAF complex; ESC: embryonic stem cell; LIF: leukaemia inhibitory factor; MEF: mouse embryonic fibroblast; MRT: malignant rhabdoid tumours; nBAF complex: neuronal BAF complex; NCBRS: Nicolaides-Baraitser syndrome; npBAF complex: neural progenitor BAF complex; PRC: Polycomb repressive complex; RTK: rhabdoid tumours of the kidney; SWI/SNF: SWItch/ sucrose non-fermentable.}

\section{Authors' contributions}

AA, NM and KK contributed to writing and editing of the manuscript. All authors read and approved the final manuscript.

\section{Acknowledgements}

We acknowledge support by Open Access Publication Fund of University of Muenster. Further, we would like to acknowledge Dr. Kiasha Govender for reviewing and editing the manuscript concerning the English language.

\section{Competing interests}

The authors declare that they have no conflict of interest.
Ethics approval and consent to participate Not applicable.

Consent for publication

Not applicable.

Availability of data and materials

Not applicable.

\section{Publisher's Note}

Springer Nature remains neutral with regard to jurisdictional claims in published maps and institutional affiliations.

Received: 12 December 2018 Accepted: 13 March 2019

Published online: 21 March 2019

References

1. Kornberg RD, Series N, May N. Chromatin structure: a repeating unit of histones and DNA chromatin structure is based on a repeating unit of eight. Society. 1974;184:868-71.

2. Wilkins MHF, Zubay G, Wilson HR. X-ray diffraction studies of the molecular structure of nucleohistone and chromosomes. J Mol Biol. 1959;1:7-10. https://doi.org/10.1016/S0022-2836(59)80046-2.

3. Bak AL, Zeuthen J, Crick FHC. High-order structure of human mitotic chromosomes. Proc Natl Acad Sci USA. 1977;74:1595-9.

4. Even-Faitelson L, Hassan-Zadeh V, Baghestani Z, Bazett-Jones DP. Coming to terms with chromatin structure. Chromosoma. 2016;125:95-110.

5. Moore LD, Le T, Fan G. DNA methylation and its basic function. Neuropsychopharmacology. 2013;38:23-38. https://doi.org/10.1038/ npp.2012.112.

6. Jin Z, Liu Y. DNA methylation in human diseases. Genes Dis. 2018;5:1-8. https://doi.org/10.1016/j.gendis.2018.01.002.

7. Bannister AJ, Kouzarides T. Regulation of chromatin by histone modifications. Cell Res. 2011;21:381-95. https://doi.org/10.1038/cr.2011.22.

8. Audia JE, Campbell RM. Histone modifications and cancer. Cold Spring Harb Perspect Biol. 2016;8:a019521.

9. Stern M, Jensen R, Herskowitz I. Five SWI genes are required for expression of the $\mathrm{HO}$ gene in yeast. J Mol Biol. 1984;178:853-68.

10. Carlson M, Osmond BC, Botstein D. Mutants of yeast defetive in sucrose utilization. Genetics. 1981;98:25-40.

11. Neigeborn L, Carlson M. Genes affecting the regulation of Suc2 gene expression by glucose repression in Saccharomyces cerevisiae. Genetics. 1984;108:845-58.

12. Neigeborn L, Carlson M. Mutations causing constitutive invertase synthesis in yeast: genetic interactions with snf mutations. Genetics. 1987:115:247-53.

13. Côté J, Quinn J, Workman JL, Peterson CL. Stimulation of GAL4 derivative binding to nucleosomal DNA by the yeast SWI/SNF complex. Science (80-). 1994:265:53-60.

14. Dingwall AK, Beek SJ, McCallum CM, Tamkun JW, Kalpana GV, Goff SP, et al. The Drosophila snr1 and brm proteins are related to yeast SWI/ SNF proteins and are components of a large protein complex. Mol Biol Cell. 1995:6:777-91.

15. Peterson CL, Tamkun JW. The SWI-SNF complex: a chromatin remodeling machine? Trends Biochem Sci. 1995:20:143-6.

16. Peterson CL, Herskowitz I. Characterization of the yeast SWI1, SWI2, and SWI3 genes, which encode a global activator of transcription. Cell. 1992;68:573-83.

17. Peterson CL, Dingwall A, Scott MP. Five SWI/SNF gene products are components of a large multisubunit complex required for transcriptional enhancement. Proc Natl Acad Sci. 1994;91:2905-8.

18. Wang W, Cote J, Xue Y, Zhou S, Khavari PA, Biggar SR, et al. Purification and biochemical heterogeneity of the mammalian SWI-SNF complex. EMBO J. 1996;15:5370-82.

19. Smith CL, Horowitz-Scherer R, Flanagan JF, Woodcock CL, Peterson CL. Structural analysis of the yeast SWI/SNF chromatin remodeling complex. Nat Struct Biol. 2003;10:141-5. 
20. Cairns BR, Kim YJ, Sayre MH, Laurent BC, Kornberg RD. A multisubunit complex containing the SWI1/ADR6, SWI2/SNF2, SWI3, SNF5, and SNF6 gene products isolated from yeast. Proc Natl Acad Sci USA. 1994;91:1950-4.

21. Papoulas O, Daubresse G, Armstrong JA, Jin J, Scott MP, Tamkun JW. The HMG-domain protein BAP111 is important for the function of the BRM chromatin-remodeling complex in vivo. Proc Natl Acad Sci USA. 2001;98:5728-33.

22. Papoulas O, Beek SJ, Moseley SL, Mccallum CM, Sarte M, Shearn A, et al. The Drosophila trithorax group proteins BRM, ASH1 and ASH2 are subunits of distinct protein complexes. Development. 1998;125:3955-66.

23. Tamkun JW, Deuring R, Scott MP, Kissinger M, Pattatucci AM, Kaufman TC, et al. Brahma: a regulator of Drosophila homeotic genes structurally related to the yeast transcriptional activator SNF2 SWI2. Cell. 1992;68:561-72.

24. Elfring $L K$, Deuring $R$, Mccallum CM, Peterson CL, Tamkunl JW. Identification and characterization of Drosophila relatives of the yeast transcriptional activator SNF2/SWI2. Mol Cell Biol. 1994;14:2225-34.

25. Wang W, Xue Y, Zhou S. Diversity and specialization of mammalian SWI/ SNF complexes. Genes Dev. 1996;10:2117-30.

26. Hargreaves DC, Crabtree GR. ATP-dependent chromatin remodeling: genetics, genomics and mechanisms. Cell Res. 2011;21:396-420. https ://doi.org/10.1038/cr.2011.32.

27. Kadoch C, Hargreaves DC, Hodges C, Elias L, Ho L, Ranish J, et al. Proteomic and bioinformatic analysis of mammalian SWI/SNF complexes identifies extensive roles in human malignancy. Nat Genet. 2013:45:592-601. https://doi.org/10.1038/ng.2628.

28. Poynter ST, Kadoch C. Polycomb and trithorax opposition in development and disease. Wiley Interdiscip Rev Dev Biol. 2016;5:659-88.

29. Khavari PA, Peterson CL, Tamkun JW, Mendel DB, Crabtree GR. BRG1 contains a conserved domain of the SWI2/SNF2 family necessary for normal mitotic growth and transcription. Nature. 1993;366:170-4.

30. Zhao K, Wang W, Rando OJ, Xue Y, Swiderek K, Kuo A, et al. Rapid and phosphoinositol-dependent binding of the SWI/SNF-like BAF complex to chromatin after T lymphocyte receptor signaling. Cell. 1998;95:625-36

31. Lessard J, Wu Jl, Ranish JA, Wan M, Winslow MM, Staahl BT, et al. An essential switch in subunit composition of a chromatin remodeling complex during neural development. Neuron. 2007;55:201-15.

32. Olave I, Wang W, Xue Y, Kuo A, Crabtree GR. Identification of a polymorphic, neuron-specific chromatin remodeling complex. Genes Dev. 2002;16:2509-17.

33. Vogel-Ciernia A, Matheos DP, Barrett RM, Kramár E, Azzawi S, Chen $Y$, et al. The neuron-specific chromatin regulatory subunit BAF53b is necessary for synaptic plasticity and memory. Nat Neurosci. 2013;16:552-61.

34. Bachmann C, Nguyen H, Rosenbusch J, Pham L, Rabe T, Patwa M, et al. mSWI/SNF (BAF) complexes are indispensable for the neurogenesis and development of embryonic olfactory epithelium. PLoS Genet. 2016;12:1-29.

35. Lickert H, Takeuchi JK, Von Both I, Walls JR, McAuliffe F, Adamson SL, et al. Baf60C is essential for function of BAF chromatin remodelling complexes in heart development. Nature. 2004:432:107-12.

36. Sun X, Hota SK, Zhou Y-Q, Novak S, Miguel-Perez D, Christodoulou D, et al. Cardiac-enriched BAF chromatin-remodeling complex subunit Baf60c regulates gene expression programs essential for heart development and function. Biol Open. 2018;7:bio029512. https://doi. org/10.1242/bio.029512.

37. Ohkawa Y, Marfella CGA, Imbalzano AN. Skeletal muscle specification by myogenin and Mef2D via the SWI/SNF ATPase Brg1. EMBO J. 2006:25:490-501.

38. Ohkawa Y, Yoshimura S, Higashi C, Marfella CGA, Dacwag CS, Tachibana T, et al. Myogenin and the SWI/SNF ATPase Brg1 maintain myogenic gene expression at different stages of skeletal myogenesis. J Biol Chem. 2007;282:6564-70.

39. de la Serna IL, Carlson KA, Imbalzano A. Mammalian SWI/SNF complexes promote MyoD-mediated muscle differentiation. Nat Genet. 2001;27:187-90.

40. Ho L, Jothi R, Ronan JL, Cui K, Zhao K, Crabtree GR. An embryonic stem cell chromatin remodeling complex, esBAF, is an essential component of the core pluripotency transcriptional network. Proc Natl Acad Sci USA. 2009;106:5187-91.

41. Ho L, Ronan JL, Wu J, Staahl BT, Chen L, Kuo A, et al. An embryonic stem cell chromatin remodeling complex, esBAF, is essential for embryonic stem cell self-renewal and pluripotency. Proc Natl Acad Sci USA. 2009;106:5181-6.

42. Cairns BR, Lorch Y, Li Y, Zhang M, Lacomis L, Erdjument-Bromage H, et al. RSC, an essential, abundant chromatin-remodeling complex. Cell. 1996;87:1249-60. https://doi.org/10.1016/S0092-8674(00)81820 -6 .

43. Muchardt C, Yaniv M. A human homologue of Saccharomyces cerevisiae SNF2/SW12 and Drosophila brm genes potentiates transcriptional activation by the glucocorticoid receptor. EMBO J. 1993;12:4279-90.

44. Phelan ML, Sif S, Narlikar GJ, Kingston RE. Reconstitution of a core chromatin remodeling complex from SWI/SNF subunits. Mol Cell. 1999;3:247-53.

45. Mashtalir N, D'Avino AR, Michel BC, Luo J, Pan J, Otto JE, et al. Modular organization and assembly of SWI/SNF family chromatin remodeling complexes. Cell. 2018;175:1272-88. https://doi.org/10.1016/j. cell.2018.09.032.

46. Wang W, Chi T, Xue Y, Zhou S, Kuo A, Crabtree GR. Architectural DNA binding by a high-mobility-group/kinesin-like subunit in mammalian SWI/SNF-related complexes. Proc Natl Acad Sci USA. 1998;95:492-8.

47. Wang W, Xue Y, Zhou S. Diversity and specialization of mammalian SWI/ SNF complexes. Genes Dev. 1996;4:2117-30.

48. Clapier CR, Iwasa J, Cairns BR, Peterson CL. Mechanisms of action and regulation of ATP-dependent chromatin-remodelling complexes. Nat Rev Mol Cell Biol. 2017;18:407-22. https://doi.org/10.1038/nrm.2017.26.

49. Whitehouse I, Flaus A, Cairns BR, White MF, Workman JL, Owen-Hughes T. Nucleosome mobilization catalysed by the yeast SWI/SNF complex. Nature. 1999:400:784-7.

50. Liu X, Li M, Xia X, Li X, Chen Z. Mechanism of chromatin remodelling revealed by the Snf2-nucleosome structure. Nature. 2017;544:440-5. https://doi.org/10.1038/nature22036.

51. Kennison JA, Tamkun JW. Dosage-dependent modifiers of polycomb and antennapedia mutations in Drosophila. Proc Natl Acad Sci. 1988;85:8136-40. https://doi.org/10.1073/pnas.85.21.8136.

52. Kennison JA. The polycomb and trithorax group proteins of drosophila: trans-regulators of homeotic gene function. Annu Rev Genet. 1995;29:289-303.

53. Ho L, Miller EL, Ronan JL, Ho WQ, Jothi R, Crabtree GR. EsBAF facilitates pluripotency by conditioning the genome for LIF/STAT3 signalling and by regulating polycomb function. Nat Cell Biol. 2011;13:903-13. https:// doi.org/10.1038/ncb2285.

54. Kaeser MD, Aslanian A, Dong MQ, Yates JR, Emerson BM. BRD7, a novel PBAF-specific SWI/SNF subunit, is required for target gene activation and repression in embryonic stem cells. J Biol Chem. 2008;283:32254-63.

55. Chi TH, Wan M, Lee PP, Akashi K, Metzger D, Chambon P, et al. Sequential roles of Brg, the ATPase subunit of BAF chromatin remodeling complexes, in thymocyte development. Immunity. 2003;19:169-82.

56. Middeljans E, Wan X, Jansen PW, Sharma V, Stunnenberg HG, Logie C. SS18 together with animal-specific factors defines human BAF-type SWI/SNF complexes. PLoS ONE. 2012;7:e33834.

57. Alpsoy A, Dykhuizen EC. Glioma tumor suppressor candidate region gene 1 (GLTSCR57) and its paralog GLTSCR57-like form SWI/SNF chromatin remodeling subcomplexes. J Biol Chem. 2018;293:3892-903.

58. Gatchalian J, Malik S, Ho J, Lee D-S, Kelso TWR, Shokhirev MN, et al. A non-canonical BRD9-containing BAF chromatin remodeling complex regulates naive pluripotency in mouse embryonic stem cells. Nat Commun. 2018;9:5139.

59. Boyer LA, Lee TI, Cole MF, Johnstone SE, Levine SS, Jenner RG, et al. Core transcriptional regulatory circuitry in human embryonic stem cells. Cell. 2005;122:947-56

60. Loh YH, Wu Q, Chew JL, Vega VB, Zhang W, Chen X, et al. The Oct4 and Nanog transcription network regulates pluripotency in mouse embryonic stem cells. Nat Genet. 2006:38:431-40.

61. Chambers I, Colby D, Robertson M, Nichols J, Lee S, Tweedie S, et al. Functional expression cloning of Nanog, a pluripotency sustaining factor in embryonic stem cells. Cell. 2003;113:643-55. 
62. Avilion AA, Nicolis SK, Pevny LH, Perez L, Vivian N, Lovell-Badge R. Multipotent cell lineages in early mouse development depend on SOX2 function. Genes Dev. 2003;17:126-40.

63. Nichols J, Zevnik B, Anastassiadis K, Niwa H, Klewe-Nebenius D, Chambers I, et al. Formation of pluripotent stem cells in the mammalian embryo depends on the POU transcription factor Oct4 Jennifer. Cell. 1998;95:379-91.

64. Bernstein BE, Mikkelsen TS, Xie X, Kamal M, Huebert DJ, Cuff J, et al. A bivalent chromatin structure marks key developmental genes in embryonic stem cells. Cell. 2006;125:315-26.

65. Zhang X, Li B, Li W, Ma L, Zheng D, Li L, et al. Transcriptional repression by the BRG1-SWI/SNF complex affects the pluripotency of human embryonic stem cells. Stem Cell Rep. 2014;3:460-74. https:// doi.org/10.1016/j.stemcr.2014.07.004.

66. Han D, Jeon S, Sohn DH, Lee C, Ahn S, Kim WK, et al. SRG3, a core component of mouse SWI/SNF complex, is essential for extra-embryonic vascular development. Dev Biol. 2008;315:136-46. https://doi. org/10.1016/j.ydbio.2007.12.024.

67. Bultman S, Gebuhr T, Yee D, La Mantia C, Nicholson J, Gilliam A, et al. A Brg1 null mutation in the mouse reveals functional differences among mammalian SWI/SNF complexes Polycomb and trithorax groups, play crucial roles in transcriptional regulation and participate in diverse processes, including cell proliferation and differentiation. Mol Cell. 2000;6:1287-95.

68. Roberts CWM, Galusha SA, McMenamin ME, Fletcher CDM, Orkin $\mathrm{SH}$. Haploinsufficiency of Snf5 (integrase interactor 1) predisposes to malignant rhabdoid tumors in mice. Proc Natl Acad Sci. 2000;97:13796-800. https://doi.org/10.1073/pnas.250492697.

69. Kidder BL, Palmer S, Knott JG. SWI/SNF-Brg1 regulates self-renewal and occupies core pluripotency-related genes in embryonic stem cells. Stem Cells. 2009;27:317-28. https://doi.org/10.1634/stemc ells.2008-0710.

70. Reyes JC, Barra J, Muchardt C, Camus A, Babinet C, Yaniv M. Altered control of cellular proliferation in the absence of mammalian brahma (SNF2a). EMBO J. 1998;17:6979-91.

71. Hanna J, Cheng AW, Saha K, Kim J, Lengner CJ, Soldner F, et al. Human embryonic stem cells with biological and epigenetic characteristics similar to those of mouse ESCs. Proc Natl Acad Sci. 2010;107:9222-7.

72. Buecker C, Chen H, Polo J, Daheron L, Bu L, Barakat S, et al. A murineES like state facilitates transgenesis and homologous recombination in human pluripotent stem cells. Cell. 2011:6:535-46.

73. Yang J, Van Oosten AL, Theunissen TW, Guo G, Silva JCR, Smith A. Stat 3 activation is limiting for reprogramming to ground state pluripotency. Cell Stem Cell. 2010;7:319-28. https://doi.org/10.1016/j. stem.2010.06.022.

74. Michel BC, D'Avino AR, Cassel SH, Mashtalir N, McKenzie ZM, McBride $\mathrm{MJ}$, et al. A non-canonical SWI/SNF complex is a synthetic lethal target in cancers driven by BAF complex perturbation. Nat Cell Biol. 2018;20:1410.

75. Staahl BT, Tang J, Wu W, Sun A, Gitler AD, Yoo AS, et al. Kinetic analysis of npBAF to nBAF switching reveals exchange of SS18 with CREST and integration with neural developmental pathways. J Neurosci. 2013;33:10348-61. https://doi.org/10.1523/JNEUROSCl.1258-13.2013.

76. Kim JK, Huh SO, Choi H, Lee KS, Shin D, Lee C, et al. Srg3, a mouse homolog of yeast SWI3, is essential for early embryogenesis and involved in brain development. Mol Cell Biol. 2001;21:7787-95.

77. Matsumoto S, Banine F, Struve J, Xing R, Adams C, Liu Y, et al. Brg1 is required for murine neural stem cell maintenance and gliogenesis. Dev Biol. 2006:289:372-83.

78. Zhan X, Shi X, Zhang Z, Chen Y, Wu Jl. Dual role of Brg chromatin remodeling factor in Sonic hedgehog signaling during neural development. Proc Natl Acad Sci. 2011;108:12758-63. https://doi. org/10.1073/pnas.1018510108.

79. Wu JI, Lessard J, Olave IA, Qiu Z, Ghosh A, Graef IA, et al. Regulation of dendritic development by neuron-specific chromatin remodeling complexes. Neuron. 2007;56:94-108.

80. Aizawa H, Hu SC, Bobb K, Balakrishnan K, Ince G, Gurevich I, et al. Dendrite development regulated by CREST, a Calcium-regulated transcriptional activator. Science. 2004;303:197.
81. Lim LP, Lau NC, Garret-Engele P, Grimson A, Schelter JM, Castle J, et al. Microarray analysis shows that some microRNAs downregulate large numbers of target mRNAs. Nature. 2005;433:769.

82. Deo M, Yu JY, Chung KH, Tippens M, Turner DL. Detection of mammalian microRNA expression by in situ hybridization with RNA oligonucleotides. Dev Dyn. 2006;235:2538-48.

83. Conaco C, Otto S, Han J-J, Mandel G. Reciprocal actions of REST and a microRNA promote neuronal identity. Proc Natl Acad Sci. 2006;103:2422-7. https://doi.org/10.1073/pnas.0511041103.

84. Lagos-Quintana M, Rauhut R, Yalcin A, Meyer J, Lendeckel W, Tuschl T. Identification of tissue-specific microRNAs from mouse. Curr Biol. 2002;12:735-9.

85. Yoo AS, Staahl BT, Chen L, Crabtree GR. MicroRNA-mediated switching of chromatin-remodelling complexes in neural development. Nature. 2009:460:642-6. https://doi.org/10.1038/nature08139.

86. Ballas N, Grunseich C, Lu DD, Speh JC, Mandel G. REST and its corepressors mediate plasticity of neuronal gene chromatin throughout neurogenesis. Cell. 2005;121:645-57. https://doi.org/10.1016/j. cell.2005.03.013.

87. Yoo AS, Sun AX, Li L, Shcheglovitov A, Portmann T, Li Y, et al. MicroRNA-mediated conversion of human fibroblasts to neurons. Nature. 2011;476:228-31.

88. Lu Y-L, Yoo AS. Mechanistic insights Into microRNA-induced neuronal reprogramming of human adult fibroblasts. Front Neurosci. 2018;12:19. https://doi.org/10.3389/fnins.2018.00522/full.

89. Parrish JZ, Kim MD, Lily YJ, Yuh NJ. Genome-wide analyses identify transcription factors required for proper morphogenesis of Drosophila sensory neuron dendrites. Genes Dev. 2006;20:820-35.

90. Arlotta P, Molyneaux BJ, Chen J, Inoue J, Kominami R, MacKlis JD. Neuronal subtype-specific genes that control corticospinal motor neuron development in vivo. Neuron. 2005:45:207-21.

91. Enomoto T, Ohmoto M, Iwata T, Uno A, Saitou M, Yamaguchi T, et al. $\mathrm{Bcl} 1 \mathrm{~b} / \mathrm{Ctip} 2$ controls the differentiation of vomeronasal sensory neurons in mice. J Neurosci. 2011;31:10159-73. https://doi.org/10.1523/ JNEUROSCI.1245-11.2011.

92. Ninkovic J, Steiner-mezzadri A, Jawerka M, Akinci U, Petricca S, Fischer J, et al. Essential role of BAF complex interacting with Pax6 in establishment of a core cross-regulatory neurogenic network. Cell Stem Cell. 2014;13:403-18.

93. Petrik D, Latchney SE, Masiulis I, Yun S, Zhang Z, Wu Jl, et al. Chromatin remodeling factor Brg1 supports the early maintenance and late responsiveness of Nestin-Lineage adult neural stem and progenitor cells. Stem Cells. 2015;33:3655-65.

94. Tuoc T, Dere E, Radyushkin K, Pham L, Nguyen H, Tonchev AB, et al. Ablation of BAF170 in developing and postnatal dentate gyrus affects neural stem cell proliferation, differentiation, and learning. Mol Neurobiol. 2016:54:4618-35.

95. John A, Brylka H, Wiegreffe C, Simon R, Liu P, Juttner R, et al. BCl1 1a is required for neuronal morphogenesis and sensory circuit formation in dorsal spinal cord development. Development. 2012;139:1831-41. https://doi.org/10.1242/dev.072850.

96. Weinberg P, Flames N, Sawa H, Garriga G, Hobert O. The SWI/SNF chromatin remodeling complex selectively affects multiple aspects of serotonergic neuron differentiation. Genetics. 2013;194:189-98.

97. Choi KY, Yoo M, Han JH. Toward understanding the role of the neuronspecific BAF chromatin remodeling complex in memory formation. Exp Mol Med. 2015;47:e155. https://doi.org/10.1038/emm.2014.129.

98. Ieda M, Fu JD, Delgado-Olguin P, Vedantham V, Hayashi Y, Bruneau $B G$, et al. Direct reprogramming of fibroblasts into functional cardiomyocytes by defined factors. Cell. 2010;142:375-86. https://doi. org/10.1016/j.cell.2010.07.002

99. Albini S, Coutinho Toto P, Dall'Agnese A, Malecova B, Cenciarelli C, Felsani A, et al. Brahma is required for cell cycle arrest and late muscle gene expression during skeletal myogenesis. EMBO Rep. 2015:16:103750. https://doi.org/10.15252/embr.201540159.

100. Mizuguchi G, Shen X, Landry J, Wu WH, Sen S, Wu C. ATP-driven exchange of histone H2AZ variant catalyzed by SWR1 chromatin remodeling complex. Science (80-). 2004;303:343-8.

101. Aoyagi S, Hayes JJ. hSWI/SNF-catalyzed nucleosome sliding does not occur solely via a twist-diffusion mechanism. Mol Cell Biol. 2002:22:7484-90. 
102. Strohner R, Wachsmuth M, Dachauer K, Mazurkiewicz J, Hochstatter J, Rippe K, et al. A "loop recapture" mechanism for ACF-dependent nucleosome remodeling. Nat Struct Mol Biol. 2005;12:683-90.

103. Blosser TR, Yang JG, Stone MD, Narlikar GJ, Zhuang X. Dynamics of nucleosome remodelling by individual ACF complexes. Nature. 2009;462:1022-7.

104. Zofall M, Persinger J, Kassabov SR, Bartholomew B. Chromatin remodeling by ISW2 and SWI/SNF requires DNA translocation inside the nucleosome. Nat Struct Mol Biol. 2006;13:339-46.

105. Saha A, Wittmeyer J, Cairns BR. Chromatin remodeling through directional DNA translocation from an internal nucleosomal site. Nat Struct Mol Biol. 2005;12:747-55.

106. Dechassa ML, Zhang B, Horowitz-scherer R, Persinger J, Woodcock CL, Peterson CL, et al. Architecture of the SWI/SNF-nucleosome complex. Mol Cell Biol. 2008;28:6010-21.

107. de Bruijn DRH, Peters WJM, de Sousa Chuva, Lopes SM, van Dijk AHA, Willemse MP, Pfundt $R$, et al. Targeted disruption of the synovial sarcoma-associated SS18 gene causes early embryonic lethality and affects PPARBP expression. Hum Mol Genet. 2006;15:2936-44.

108. Wiegand KC, Shah SP, Al-Agha IM, Yongjun Z, Tse K, Zeng T, et al. ARID1A mutations in endometriosis-associated ovarian carcinomas kimberly. N Engl J Med. 2010;363:1532-43.

109. Zhao Y, Tse K, Sc B, Zeng T, Sc M, Senz J, et al. Mutations in endometriosis-associated ovarian carcinomas. N Engl J Med. 2010:363:1532-43.

110. Slifer E. A mutant stock of Drosophila with extra sex combs. J Exp Zool Banner. 1942;90:31-40.

111. McKenzie Duncan I. Polycomblike: a gene that appears to be required for the normal expression of the bithorax and antennapedia gene complexes of Drosophila melanogaster. Genetics. 1982;102:49-70.

112. Ingham PW. A gene that regulates the bithorax complex differentially in larval and adult cells of Drosophila. Cell. 1984:37:815-23.

113. Jürgens $G$. A group of genes controlling the spatial expression of the bithorax complex in Drosophila. Nature. 1985;316:153-5.

114. Breen TR, Duncan IM. Maternal expression of genes that regulate the bithorax complex of Drosophila melanogaster. Dev Biol. 1986;118:442-56.

115. Dura JM, Brock HW, Santamaria P. Polyhomeotic: a gene of Drosophila melanogaster required for correct expression of segmental identity. MGG Mol Gen Genet. 1985;198:213-20.

116. Cao R, Zhang Y. SUZ12 is required for both the histone methyltransferase activity and the silencing function of the EED-EZH2 complex. Mol Cell. 2004:15:57-67.

117. Pasini D, Bracken AP, Jensen MR, Denchi EL, Helin K. Suz12 is essential for mouse development and for $\mathrm{EZ} \mathrm{H} 2$ histone methyltransferase activity. EMBO J. 2004;23:4061-71.

118. Copeland RA, Solomon ME, Richon VM. Protein methyltransferases as a target class for drug discovery. Nat Rev Drug Discov. 2009;8:724-32. https://doi.org/10.1038/nrd2974.

119. Hansen KH, Bracken AP, Pasini D, Dietrich N, Gehani SS, Monrad A, et al. A model for transmission of the H3K27me3 epigenetic mark. Nat Cell Biol. 2008:10:1291-300.

120. Hathaway NA, Bell O, Hodges C, Miller EL, Neel DS, Crabtree GR. Dynamics and memory of heterochromatin in living cells nathaniel. Cell. 2012;149:1447-60.

121. Kadoch C, Williams RT, Calarco JP, Miller EL, Weber CM, Braun SMG, et al. Dynamics of BAF-Polycomb complex opposition on heterochromatin in normal and oncogenic states. Nat Genet. 2017;49:213-22. https://doi. org/10.1038/ng.3734.

122. Stanton BZ, Hodges C, Calarco JP, Braun SMG, Ku WL, Kadoch C, et al. Smarca4 ATPase mutations disrupt direct eviction of PRC1 from chromatin. Nat Genet. 2017;49:282-8. https://doi.org/10.1038/ng.3735.

123. Hodges HC, Stanton BZ, Cermakova K, Chang CY, Miller EL, Kirkland $J G$, et al. Dominant-negative SMARCA4 mutants alter the accessibility landscape of tissue-unrestricted enhancers. Nat Struct Mol Biol. 2018;25:61-72. https://doi.org/10.1038/s41594-017-0007-3.

124. Kosho T, Miyake N, Carey JC. Coffin-Siris syndrome and related disorders involving components of the BAF (mSWI/SNF) complex: historical review and recent advances using next generation sequencing. Am J Med Genet Part C Semin Med Genet. 2014;166:241-51.

125. Coffin GS, Siris E. Mental retardation with absent fifth fingernail and terminal phalanx. Am J Dis Child. 1970;119:433-9.
126. Levy P, Baraitser M. Coffin-Siris syndrome. J Med Genet. 1991;28:338-41.

127. Schrier SA, Bodurtha JN, Burton B, Chudley AE, Chiong MAD, D'avanzo $M G$, et al. The Coffin-Siris syndrome: a proposed diagnostic approach and assessment of 15 overlapping cases. Am J Med Genet Part A. 2012;158(1):1865-76.

128. Wieczorek D, Bögershausen N, Beleggia F, Steiner-Haldenstätt S, Pohl E, Li Y, et al. A comprehensive molecular study on Coffin-Siris and Nicolaides-Baraitser syndromes identifies a broad molecular and clinical spectrum converging on altered chromatin remodeling. Hum Mol Genet. 2013;22:5121-35.

129. Santen GWE, Aten E, Vulto-van Silfhout AT, Pottinger C, van Bon $B W M$, van Minderhout IJHM, et al. Coffin-Siris syndrome and the BAF complex: genotype-phenotype study in 63 patients. Hum Mutat. 2013;34:1519-28

130. Wright CF, McRae JF, Clayton S, Gallone G, Aitken S, FitzGerald TW, et al. Making new genetic diagnoses with old data: iterative reanalysis and reporting from genome-wide data in 1133 families with developmental disorders. Genet Med. 2018;20:1216. https://doi.org/10.1038/ gim.2017.246.

131. Tsurusaki Y, Okamoto N, Ohashi H, Kosho T, Imai Y, Hibi-Ko Y, et al. Mutations affecting components of the SWI/SNF complex cause Coffin-Siris syndrome. Nat Genet. 2012;44:376-8. https://doi.org/10.1038/ng.2219.

132. Kosho T, Okamoto N, Ohashi H, Tsurusaki Y, Imai Y, Hibi-Ko Y, et al. Clinical correlations of mutations affecting six components of the SWI/ SNF complex: detailed description of 21 patients and a review of the literature. Am J Med Genet Part A. 2013;161:1221-37.

133. Miyake N, Abdel-Salam G, Yamagata T, Eid MM, Osaka H, Okamoto N, et al. Clinical features of SMARCA2 duplication overlap with Coffin-Siris syndrome. Am J Med Genet Part A. 2016;170:2662-70.

134. Tsurusaki Y, Okamoto N, Ohashi H, Mizuno S, Matsumoto N, Makita Y, et al. Coffin-Siris syndrome is a SWI/SNF complex disorder. Clin Genet. 2014;85:548-54.

135. Versteege I, Sévenet $N$, Lange J, Rousseau-Merck M-F, Ambros $P$, Handgretinger R, et al. Truncating mutations of hSNF5 in aggressive paediatric cancer. Nature. 1998:394:203-6.

136. Kosho T, Okamoto N, Imai Y, Ohashi H, van Eerde AM, Chrzanowska K, et al. Genotype-phenotype correlation of Coffin-Siris syndrome caused by mutations in SMARCB1, SMARCA4, SMARCE1, and ARID1A. Am J Med Genet Part C Semin Med Genet. 2014;166:262-75.

137. Nicolaides P, Baraitser M. An unusual syndrome with mental retardation and sparse hair. Clin Dysmorphol. 1993;2:232-6.

138. Van Houdt JKJ, Nowakowska BA, Sousa SB, Van Schaik BDC, Seuntjens E, Avonce N, et al. Heterozygous missense mutations in SMARCA2 cause Nicolaides-Baraitser syndrome. Nat Genet. 2012;44:445-9. https://doi. org/10.1038/ng.1105.

139. Sousa SB, Hennekam RC, Abdul-Rahman O, Alders M, Azzarello-Burri S, Bottani A, et al. Phenotype and genotype in Nicolaides-Baraitser syndrome. Am J Med Genet Part C Semin Med Genet. 2014;166:302-14.

140. Ejaz R, Babul-Hirji R, Chitayat D. The evolving features of NicolaidesBaraitser syndrome-a clinical report of a 20-year follow-up. Clin Case Rep. 2016:4:351-5.

141. Kleefstra T, Brunner HG, Amiel J, Oudakker AR, Nillesen WM, Magee $A$, et al. Loss-of-function mutations in euchromatin histone methyl transferase 1 (EHMT1) cause the 9q34 subtelomeric deletion syndrome. Am J Hum Genet. 2006;79:370-7.

142. Kleefstra T, Kramer JM, Neveling K, Willemsen MH, Koemans TS, Vissers LELM, et al. Disruption of an EHMT1-associated chromatin-modification module causes intellectual disability. Am J Hum Genet. 2012;91:73-82.

143. Neale B, Devlin B, Boone BE, Levy SE, Lihm J, Buxbaum JD, et al. Patterns and rates of exonic de novo mutations in autism spectrum disorders. Nature. 2012;485:242-6. https://doi.org/10.1038/nature11011.

144. O'Roak BJ, Vives L, Girirajan S, Karakoc E, Krumm N, Coe BP, et al. Sporadic autism exomes reveal a highly interconnected protein network of de novo mutations. Nature. 2012:485:246-50. https://doi.org/10.1038/ nature10989.

145. Chesi A, Staahl BT, Jovicic A, Couthouis J, Fasolino M, Raphael AR, et al. Exome sequencing to identify de novo mutations in sporadic ALS trios. Nat Neurosci. 2013;16:851.

146. Koga M, Ishiguro H, Yazaki S, Horiuchi Y, Arai M, Niizato K, et al. Involvement of SMARCA2/BRM in the SWI/SNF chromatin-remodeling complex in schizophrenia. Hum Mol Genet. 2009;18:2483-94. 
147. Basak A, Hancarova M, Ulirsch JC, Balci TB, Trkova M, Pelisek M, et al. BCL11A deletions result in fetal hemoglobin persistence and neurodevelopmental alterations. J Clin Invest. 2015;125:2363-8.

148. Sokpor G, Xie Y, Rosenbusch J, Tuoc T. Chromatin remodeling BAF (SWI/SNF) complexes in neural development and disorders. Front Mol Neurosci. 2017;10:1-22. https://doi.org/10.3389/fnmol.2017.00243/full.

149. Bögershausen N, Wollnik B. Mutational landscapes and phenotypic spectrum of SWI/SNF-related intellectual disability disorders. Front Mol Neurosci. 2018;11:1-18. https://doi.org/10.3389/fnmol.2018.00252/full.

150. Son EY, Crabtree GR. The role of BAF (mSWI/SNF) complexes in mammalian neural development. Am J Med Genet Part C Semin Med Genet. 2014;166:333-49.

151. Kadoch C, Crabtree GR. Reversible disruption of mSWI/SNF (BAF) complexes by the SS18-SSX oncogenic fusion in synovial sarcoma. Cell. 2013;153:71-85. https://doi.org/10.1016/j.cell.2013.02.036.

152. Hasselblatt M, Isken $S$, Linge A, Eikmeier K, Jeibmann A, Oyen F, et al. High-resolution genomic analysis suggests the absence of recurrent genomic alterations other than SMARCB1 aberrations in atypical teratoid/rhabdoid tumors. Genes Chromosom Cancer. 2013;52:185-90.

153. Roberts CWM, Leroux MM, Fleming MD, Orkin SH. Highly penetrant, rapid tumorigenesis through conditional inversion of the tumor suppressor gene Snf5. Cancer Cell. 2002;2:415-25.

154. Wang X, Werneck MBF, Wilson BG, Kim H-J, Kluk MJ, Thom CS, et al. TCR-dependent transformation of mature memory phenotype $T$ cells in mice. J Clin Invest. 2011;121:3834-45.

155. Modena P, Lualdi E, Facchinetti F, Galli L, Teixeira MR, Pilotti S, et al. SMARCB1/INI1 tumor suppressor gene is frequently inactivated in epithelioid sarcomas. Cancer Res. 2005;65:4012-9.

156. Doan DN, Veal TM, Yan Z, Wang W, Jones SN, Imbalzano AN. Loss of the INI1 tumor suppressor does not impair the expression of multiple BRG1-dependent genes or the assembly of SWI/SNF enzymes. Oncogene. 2004;23:3462-73.

157. Jamshidi F, Bashashati A, Shumansky K, Dickson B, Gokgoz N, Wunder $J S$, et al. The genomic landscape of epithelioid sarcoma cell lines and tumours. J Pathol. 2016;238:63-73.

158. Nakayama RT, Pulice JL, Valencia AM, McBride MJ, McKenzie ZM, Gillespie MA, et al. SMARCB1 is required for widespread BAF complexmediated activation of enhancers and bivalent promoters. Nat Genet. 2017:49:1613-23. https://doi.org/10.1038/ng.3958.

159. Wilson BG, Wang $X$, Shen $X$, Mckenna ES, Madeleine $E$, Cho Y, et al. Epigenetic antagonism between polycomb and SWI/SNF complexes during oncogenic transformation. Cancer Cell. 2011;18:316-28.

160. Sauvageau M, Sauvageau G. Polycomb group proteins: multifaceted regulators of somatic stem cells and cancer. Cell Stem Cell. 2010;7:299-313

161. Oruetxebarria I, Venturini F, Kekarainen T, Houweling A, Zuijderduijn LMP, Mohd-sarip A, et al. p16 INK4a is required for hSNF5 chromatin remodeler-induced cellular senescence in malignant rhabdoid tumor cells. J Biol Chem. 2004;279:3807-16.

162. Knutson SK, Warholic NM, Wigle TJ, Klaus CR, Allain CJ, Raimondi A, et al. Durable tumor regression in genetically altered malignant rhabdoid tumors by inhibition of methyltransferase EZH2. Proc Natl Acad Sci. 2013:110:7922-7. https://doi.org/10.1073/pnas.1303800110.

163. Alimova I, Birks DK, Harris PS, Knipstein JA, Venkataraman S, Marquez $V E$, et al. Inhibition of EZH2 suppresses self-renewal and induces radiation sensitivity in atypical rhabdoid teratoid tumor cells. Neuro Oncol. 2013;15:149-60

164. Fioravanti R, Stazi G, Zwergel C, Valente S, Six Mai A. Years (2012-2018) of researches on catalytic EZH2 inhibitors: the boom of the 2-pyridone compounds. Chem Rec. 2018. https://doi.org/10.1002/tcr.201800091.

165. Gulati N, Béguelin W, Giulino-Roth L, Eguelin WB. Enhancer of zeste homolog 2 (EZH2) inhibitors. Leuk Lymphoma. 2018. 59. http://www. tandfonline.com/action/journallnformation?journalCode=ilal20. Accessed 2 Nov 2018

166. Januario T, Ye X, Bainer R, Alicke B, Smith T, Haley B, et al. PRC2-mediated repression of SMARCA2 predicts EZH2 inhibitor activity in SWI/SNF mutant tumors. Proc Natl Acad Sci. 2017;114:12249-54. https://doi. org/10.1073/pnas.1703966114.

167. Hoffman GR, Rahal R, Buxton F, Xiang K, McAllister G, Frias E, et al. Functional epigenetics approach identifies BRM/SMARCA2 as a critical synthetic lethal target in BRG1-deficient cancers. Proc Natl Acad Sci. 2014;111:3128-33. https://doi.org/10.1073/pnas.1316793111.

168. Wilson BG, Helming KC, Wang X, Kim Y, Vazquez F, Jagani Z, et al. Residual complexes containing SMARCA2 (BRM) underlie the oncogenic drive of Smarca4 (Brg1) mutation. Mol Cell Biol. 2014;34:1136-44.

169. Vangamudi B, Paul TA, Shah PK, Kost-Alimova M, Nottebaum L, Shi X, et al. The SMARCA2/4 ATPase domain surpasses the bromodomain as a drug target in SWI/SNF mutant cancers: insights from CDNA rescue and PFI-3 inhibitor studies. Cancer Res. 2015;75:3865-78.

170. Krämer KF, Moreno N, Frühwald MC, Kerl K. BRD9 inhibition, alone or in combination with cytostatic compounds as a therapeutic approach in rhabdoid tumors. Int J Mol Sci. 2017:18:1-12.

171. Witkowski L, Carrot-Zhang J, Albrecht S, Fahiminiya S, Hamel N, Tomiak E, et al. Germline and somatic SMARCA4 mutations characterize small cell carcinoma of the ovary, hypercalcemic type. Nat Genet. 2014;46:438-43. https://doi.org/10.1038/ng.2931.

172. Ramos P, Karnezis AN, Hendricks WPD, Wang Y, Tembe W, Zismann VL, et al. Loss of the tumor suppressor SMARCA4 in small cell carcinoma of the ovary, hypercalcemic type (SCCOHT). Rare Dis. 2014;2:e967148. https://doi.org/10.4161/2167549X.2014.967148.

173. The Cancer Genome Atlas Research Network. Integrated genomic characterization of endometrial carcinoma. Nature. 2013;497:67-73.

174. Muzny DM, Bainbridge MN, Chang K, Dinh HH, Drummond JA, Fowler $\mathrm{G}$, et al. Comprehensive molecular characterization of human colon and rectal cancer. Nature. 2012;487:330-7. https://doi.org/10.1038/ nature11252.

175. Biankin AV, Waddell N, Kassahn KS, Gingras M, Muthuswamy LB, Johns $\mathrm{AL}$, et al. Pancreatic cancer genomes reveal aberrations in axon guidance pathway genes. Nature. 2012;491:399-405.

176. Wang K, Kan J, Yuen ST, Shi ST, Chu KM, Law S, et al. Exome sequencing identifies frequent mutation of ARID1 A in molecular subtypes of gastric cancer. Nat Genet. 2011;43:1219-23. https://doi.org/10.1038/ng.982.

177. Wang K, Yuen ST, Xu J, Lee SP, Yan HHN, Shi ST, et al. Whole-genome sequencing and comprehensive molecular profiling identify new driver mutations in gastric cancer. Nat Genet. 2014;46:573-82. https://doi. org/10.1038/ng.2983.

178. Varela I, Tarpey P, Raine K, Huang D, Ong CK, Stephens P, et al. Exome sequencing identifies frequent mutation of the SWI/SNF complex gene PBRM1 in renal carcinoma. Nature. 2011;469:539-42. https://doi. org/10.1038/nature09639.

179. Kim SS, Kim MS, Yoo NJ, Lee SH. Frameshift mutations of a chromatinremodeling gene SMARCC2 in gastric and colorectal cancers with microsatellite instability. Apmis. 2013;121:168-9.

180. Stephens PJ, Tarpey PS, Davies H, Van Loo P, Wedge DC, Nik-Zainal S, et al. The landscape of cancer genes and mutational processes in breast cancer. Nature. 2012;486:400-4 (PMID: 22722201)

181. Clark J, Rocques PJ, Crew AJ, Gill S, Shipley J, Chan AML, et al. Identification of novel genes, SYT and SSX, involved in the $t(X ; 18)(p 11.2 ; q 11.2)$ translocation found in human synovial sarcoma. Nat Genet. 1994;7:502-8.

182. Crew AJ, Clark J, Fisher C, Gill S, Grimer R, Chand A, et al. Fusion of SYT to two genes, SSX1 and SSX2, encoding proteins with homology to the Kruppel-associated box in human synovial sarcoma. Eur Mol Biol Organ J. 1995;14:2333-40.

183. Brodin B, Haslam K, Yang K, Bartolazzi A, Xie Y, Starborg M, et al. Cloning and characterization of spliced fusion transcript variants of synovial sarcoma: SYT/SSX4, SYT/SSX4V, and SYT/SSX2v. Possible regulatory role of the fusion gene product in wild type SYT expression. Gene. 2001;268:173-82.

184. McBride MJ, Pulice JL, Beird HC, Ingram DR, Davino AR, Shern JF, et al. The SS18-SSX fusion oncoprotein hijacks BAF complex targeting and function to drive synovial sarcoma. Cancer Cell. 2018;33:1-14. https:// doi.org/10.1016/j.ccell.2018.05.002.

185. Naka N, Takenaka S, Araki N, Miwa T, Hashimoto N, Yoshioka K, et al. Synovial sarcoma is a stem cell malignancy. Stem Cells. 2010;28:1119-31.

186. Banito A, Li X, Laporte AN, Roe J-S, Sanchez-Vega F, Huang C-H, et al. The SS18-SSX oncoprotein hijacks KDM2B-PRC1.1 to drive synovial sarcoma. Cancer Cell. 2018;34:346-8.

187. Druker BJ. Translation of the Philadelphia chromosome into therapy for CML. Blood. 2008;112:4808-18. 
188. Druker BJ, Guilhot F, O'Brien SG, Gathmann I, Kantarjian H, Gattermann $\mathrm{N}$, et al. Five-year follow-up of patients receiving imatinib for chronic myeloid leukemia. N Engl J Med. 2006;355:2408-17. https://doi. org/10.1056/NEJMoa062867.

189. Kadoch C, Crabtree GR. Mammalian SWI/SNF chromatin remodeling complexes and cancer: mechanistic insights gained from human genomics. Sci Adv. 2015;1:1-17.
190. Brien GL, Remillard D, Shi J, Hemming ML, Chabon J, Wynne K, et al. Targeted degradation of BRD9 reverses oncogenic gene expression in synovial sarcoma. Elife. 2018;7:1-26.
Ready to submit your research? Choose BMC and benefit from:

- fast, convenient online submission

- thorough peer review by experienced researchers in your field

- rapid publication on acceptance

- support for research data, including large and complex data types

- gold Open Access which fosters wider collaboration and increased citations

- maximum visibility for your research: over $100 \mathrm{M}$ website views per year

At BMC, research is always in progress.

Learn more biomedcentral.com/submissions 